\title{
Bone Repair and Regeneration
}

\section{Editorial Comment}

\author{
Georg N. Duda
}

Published online: 11 August 2011

(C) The Association of Bone and Joint Surgeons (B) 2011

Regenerative therapies for bone and muscle reconstitution require understanding of both biologic and mechanical conditions. Even though this is well known, its implications for clinical therapies are only to a limited degree recognized. The goal of this symposium was to initiate discussion on the cellular, tissue, and organ levels, formulate current concepts in musculoskeletal regeneration, and promote the translation of their techniques into the clinic.

Recent advances in both musculoskeletal biomechanics and molecular and cell biologic approaches in tissue engineering have led to high expectations among scientists, clinicians, and patients, especially in joint and bone reconstruction. Mechanobiology plays here a central role in linking mechanotransduction and tissue engineering with macroscopic tissue behavior and characteristics of native and artificial biomaterials. Successful translation to clinical practice additionally requires extensive interaction with physicians. By initiating discussion and interaction between the basic disciplines involved in investigating the regeneration of musculoskeletal tissues, together with clinical partners, we aim to identify strategic areas within and interactions between the disciplines that are essential for bringing new therapies to the clinic (Fig. 1).

The work from Ball et al. [1] reflects recent developments in bio-inspired nanomaterials and tissue regeneration of bone. Engineering of large volumes of bone in vivo

G. N. Duda $(\square)$

Julius Wolff Institute and Center for Musculoskeletal Surgery,

Charité-Universitätsmedizin Berlin, Augustenburger Platz 1,

Berlin 13353, Germany

e-mail: georg.duda@charite.de

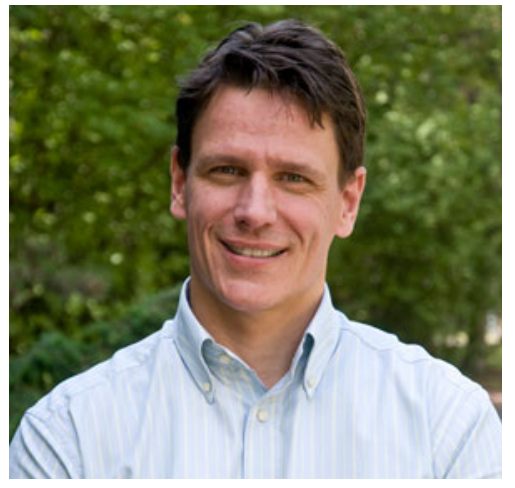

Fig. 1 Dr. Georg N. Duda is shown.

seems applicable; however, a thorough materials analysis of tissue-engineered bone still remains mandatory to come to an understanding of native tissue formation. Willie et al. [7] present an approach to vary fixation stiffness and describe how stiffness affects bone healing in rat osteotomies. Mehta et al. [4] describe delayed bone healing in female aged rats compared to male rats and how mechanical stimulation affects tissue formation and maturation between the genders. Johnson et al. [2] explain the highly metabolic and vascularized bone tissue essential for normal growth and repair. A logical strategy to promote healing is therefore to deliver factors that stimulate increased or accelerated vascular growth. Effective sustained delivery of small-molecule activators of specific pathways open new and exciting therapeutic approaches. Kolar et al. [3] analyzed hematoma in patients with autoimmune diseases or otherwise restricted immune functions. They compared these hematoma samples with ones from otherwise healthy controls and found an upregulation of specific immune cells. Other work [5] has 
also recently illustrated specific subsets of immune cells apparently relevant for prompt healing. These studies raise the question to what degree the early immune response in healing should be differentiated in a more and in a less beneficial phase to bone healing. If so, treatment modalities should specifically address the distinct aspects of the immune responses after injury. Finally and from a completely different perspective, von Domarus et al. [6] describe the relevance of vitamin $\mathrm{D}$ for skeletal health and cancer prevention. Such a link is important to understand since a substantial portion of the global population suffers from a vitamin $\mathrm{D}$ deficit.

It will be of importance for the future care of patients with fractures to better understand bone regeneration and healing from the standpoint of influencing factors, such as the immune status, bone metabolism, and gender-specific aspects of healing. The comprehensive view of the patient itself and the modalities of treatment currently available present a great chance to come to a realistic understanding of deficits in healing and-in a true sensea personalized medical approach in musculoskeletal surgery.

\section{References}

1. Ball MD, Bonzani IC, Bovis MJ, Williams A, Stevens MM. Human periosteum is a source of cells for orthopaedic tissue engineering: a pilot study. Clin Orthop Relat Res. 2011 May 6 [Epub ahead of print].

2. Johnson MR, Boerckel JD, Dupont KM, Guldberg RE. Functional restoration of critically sized segmental defects with bone morphogenetic protein-2 and Heparin treatment. Clin Orthop Relat Res. DOI:10.1007/s11999-011-2012-х.

3. Kolar P, Gaber T, Perka C, Duda GN, Buttgereit F. Human early fracture hematoma is characterized by inflammation and hypoxia. Clin Orthop Relat Res. 2011 March 16 [Epub ahead of print].

4. Mehta M, Duda GN, Perka C, Strube P. Influence of gender and fixation stability on bone defect healing in middle-aged rats: a pilot study. Clin Orthop Relat Res. 2011 May 18 [Epub ahead of print].

5. Toben D, Schroeder I, El Khassawna T, Mehta M, Hoffmann JE, Frisch JT, Schell H, Lienau J, Serra A, Radbruch A, Duda GN. Fracture healing is accelerated in the absence of the adaptive immune system. J Bone Miner Res. 2011;26:113-124.

6. von Domarus C, Brown J, Barvencik F, Amling M, Pogoda P. How much vitamin D do we need for skeletal health? Clin Orthop Relat Res. 2011 March 30 [Epub ahead of print].

7. Willie BM, Blakytny R, Glöckelmann M, Ignatius A, Claes L. Temporal variation in fixation stiffness affects healing by differential cartilage formation in a rat osteotomy model. Clin Orthop Relat Res. 2011 March 17 [Epub ahead of print]. 